\title{
Anti-hyperglycemic effect of Vicia ervilia (L.) Willd (Fabaceae) seed extract and its effect on lipid profile, and hepatic and renal biomarkers in streptozotocin-induced diabetic rats
}

\author{
Derya Kartal, Necati Özok* \\ Department of Biology, Faculty of Science, Van Yüzüncü Yıl University, 65080, Tuşba, Van, Turkey \\ *For correspondence: Email: necatiozok@yyu.edu.tr; Tel: +90 432 2251051; Fax: +90 4322251188 \\ Sent for review: 6 February 2019 \\ Revised accepted: 19 August 2019
}

\begin{abstract}
Purpose: To evaluate the impact of Vicia ervilia (L.) Willd (Fabaceae) lyophilized extract on various biomarkers of streptozotocin-induced diabetic rats.

Methods: Adult male rats (36) were divided into 6 groups, viz, normal control (NC), diabetes control (DC), and treatment groups. Experimental diabetes was induced with streptozotocin. Blood samples were taken from the tail veins daily for 25 days. Fasting and postprandial blood glucose levels of rats were determined. The rats were sacrificed and blood, kidney and liver were taken for biochemical analysis.

Results: Blood glucose decreased in DC groups compared to NC group ( $p \leq 0.05)$. In diabetic extract groups, glycated $\mathrm{Hb}$ decreased compared to DC group $(p \leq 0.05)$. Alpha glucosidase activity was reduced in all treatment groups compared to $D C$ group $(p \leq 0.05)$. Only triglyceride levels of diabetes extract $(400 \mathrm{mg} / \mathrm{mL})$ group decreased compared to $D C(p \leq 0.05)$. Total cholesterol levels fell compared to NC and DC groups ( $p \leq 0.05)$. Low density lipoprotein was lower compared to NC $(p \leq 0.05)$, while aspartate aminotransferase and alanine aminotransferase levels rose in diabetic extract groups compared to $N C$, but fell in some diabetic extract groups compared to DC group $(p \leq 0.05)$. Lactate dehydrogenase decreased in all diabetic extract groups compared to $N C$ and $D C(p \leq 0.05)$. Serum urea and creatinine levels were higher in diabetic extract groups compared to NC, but decreased in DC group ( $p \leq 0.05)$.

Conclusion: These findings demonstrate that Vicia ervilia lyophilized extract haas positive effects on blood glucose and biochemical parameters in diabetic rats compared to DC of V. ervilia seed extract.
\end{abstract}

Keywords: Antidiabetic, Diabetes mellitus, Lipid profile, Diabetic nephropathy, Liver damage, Streptozotocin, Vicia ervilia

This is an Open Access article that uses a fund-ing model which does not charge readers or their institutions for access and distributed under the terms of the Creative Commons Attribution License (http://creativecommons.org/licenses/by/4.0) and the Budapest Open Access Initiative (http://www.budapestopenaccessinitiative.org/read), which permit unrestricted use, distribution, and reproduction in any medium, provided the original work is properly credited.

Tropical Journal of Pharmaceutical Research is indexed by Science Citation Index (SciSearch), Scopus, International Pharmaceutical Abstract, Chemical Abstracts, Embase, Index Copernicus, EBSCO, African Index Medicus, JournalSeek, Journal Citation Reports/Science Edition, Directory of Open Access Journals (DOAJ), African Journal Online, Bioline International, Open-J-Gate and Pharmacy Abstracts

\section{INTRODUCTION}

Diabetes mellitus (DM) is defined as hyperglycemia caused by inadequate production or insufficient biological activity of insulin, resulting in microvascular and macrovascular complications. This chronic and incurable disease is responsible for millions of deaths per year and limits the lives of many people with lifethreatening complications [1]. In hyperglycemia, 
an excess of free radicals is produced as a result of the autoxidation of glucose and proteins [2].

Recently, attention has been focused on the relationship between free radicals and DM development and progression A significant increase in the reactive oxygen species due to the decrease in antioxidant activity causes structural deterioration in macromolecules and consequently dysfunction [3]. Type II Diabetes Mellitus is a metabolic sickness that impacts about half a million humans worldwide. It is defined as hyperglycemia, but it is also characterized by hyperlipidemia, oxidative stress and increased protein glycation [4].

Current oral hypoglycemic agents have fewer side effects than synthetic agents, although they have side effects such as skin reactions, hematological disorders and increased hepatic enzymes [5]. Despite the development of pharmacological agents to treat diabetes, the use of therapeutic plants is considered a complementary remedy for this disease. The herbal treatment methods used in the treatment of diseases have been transferred through generations. Nowadays, in the light of this information, it has been important to explore the healing effects of bioactive compounds [6].

Plants and their derivatives have been used for the treatment of DM for thousands of years and are often thought to be less toxic and less adverse than their synthetic equivalents. For this reason, herbal medicines have long been used in the treatment of DM worldwide [7]. The genus Vicia is one the of perennial herbaceous plants. There are about 60 wild species in Turkey. It is used as animal feed. Vetch [Vicia ervilia (L.) Willd. (Fabaceae)] is traditionally used in the treatment of diabetes [8]. However, scientific research on the therapeutic effects of this plant is limited. Scientific studies have been carried out on plants that may be used as alternatives to synthetic drugs used to treat diabetes worldwide.

\section{EXPERIMENTAL}

\section{Plant material and preparation of extracts}

Vicia ervilia plant seeds were obtained from local agricultural growers from the province. The seeds were germinated in Van Yüzüncü Yıl University Botanic Laboratory and the species was diagnosed (Dr Süleyman Mesut Pınar VYYÜ Science Faculty). This herbarium specimen (no. $164097)$ is preserved in the Herbarium of the Faculty of Science of Van Yüzüncü Yıl University (VANF). The seeds of this plant were prepared according to the method of preparation of the local population in the treatment of diabetes (Seeds were washed under hygienic conditions and dried in the shade. Slightly roasted and pulverized and used after the bottom sieving). A mixture of $1000 \mathrm{ml}$ of purified water and $50 \mathrm{~g}$ of seed extract was prepared. This mixture was shaken on the digital shaker for $24 \mathrm{~h}$. Filtered through filter paper. The filtrate was concentrated in an evaporator. Concentrated filtrate was placed in falcon tubes and kept at $-80{ }^{\circ} \mathrm{C}$ for 48 h. Frozen falcon tubes were lyophilized (at -51 ${ }^{\circ} \mathrm{C}$ temperature and 50 mTorr under pressure). The dried extract was pulverized in porcelain mortar and stored at $4{ }^{\circ} \mathrm{C}$ for use in the study [9].

\section{Animals}

Animal care and experimental practices were performed according to the American Society of Physiology's animal care and use guidelines [10]. Wistar albino male rats (56 rats, weighing 200 $350 \mathrm{~g}$ ) were obtained from Van Yüzüncü Yıl University Experimental Animal Unit. The rats were adapted to the laboratory conditions $(12 \mathrm{~h}$ photoperiod and $22 \pm 1.5^{\circ} \mathrm{C}$ ) for two weeks. The animals were given standard feed and tap water during the experiment. Control group and diabetic group rats were weighed every 5 days for 25 days and weighing values were recorded. This investigation was confirmed by Van 100 Yıl University Anımal Experıments Local Ethıcs Commıttee (YÜHADYEK) (Protocol no: 2014/02).

\section{Acute toxicity tests}

For the acute toxicity test, 15 rats were divided into three groups. This test was performed according to OECD Guideline 425. Lyophilized seed extract $(2000,5000$ and $10000 \mathrm{mg} / \mathrm{kg}$ rat bw) was administered orally to rats by gavage. Rats were observed for the first 30 minutes and every four hours for the first 24 hours (for behavioral, physical and pharmacological toxic effects) [11].

\section{Experimental design}

Group 1 - normal control (NC) rats received distilled water (1 ml/kg, i.p.), Group 2 - diabetic control (DC); Group 3 - diabetes+acarbose 20 $\mathrm{mg} / \mathrm{kg}$ group (DAC), Group 4 - diabetes+ extract $100 \mathrm{mg} / \mathrm{kg}$ group (DMV100), Group 5 diabetes+ extract $200 \mathrm{mg} / \mathrm{kg}$ group (DMV200), Group 6. diabetes+ extract $400 \mathrm{mg} / \mathrm{kg}$ group (DMV400).

\section{Preparation of tissue supernatant}

The rats were intraperitoneally anesthetized with ketamine at the end of this study (5 mg/100 g, ip) 
[12]. The blood samples were acquired from a heart perforation. Blood samples were placed in EDTA and biochemistry tubes. EDTA tubes were used to determine glycosylated hemoglobin (HbA1c) levels and to prepare erythrocyte platelets. Biochemistry tubes were centrifuged at $4000 \mathrm{rpm}$ for 15 minutes at $4{ }^{\circ} \mathrm{C}$ for blood serum analyzes. The tissues of the rats were washed with physiological water and maintained in the freezer $\left(-80^{\circ} \mathrm{C}\right)$ until the time of analysis. For tissue homogenization, the small intestine tissues were allowed to dissolve gradually until they reached room temperature. After weighing 1 $\mathrm{g}$ of tissue, $5 \mathrm{~mL}$ of cold buffer was added. The tissues were homogenized in ultrasonic homogenizer for 5 minutes (Jencons Scientific Co., Bedfordshire, UK, $20 \mathrm{kHz}$ frequency ultrasonic,). The homogenates were centrifuged in a cooled centrifuge device (Hettich Universal $320 \mathrm{R})$ at $9500 \mathrm{rpm}$ for $30 \mathrm{~min}$ at $4{ }^{\circ} \mathrm{C}$. Alphaglucosidase enzyme activity was measured in the supernatants obtained from small intestine tissues [13].

\section{Induction of experimental diabetes mellitus and measurement of blood glucose level}

Animals were fasted for $12 \mathrm{~h}$ overnight before streptozotocin injection. Streptozotocin $(0.1 \mathrm{M}$, $\mathrm{pH}$ 4.5) was administered intraperitoneally after dissolution in the citrate buffer [ $50 \mathrm{mg} / \mathrm{kg}$ (i.p)]. Blood glucose values of rats after 72 hours were measured by glucometer. Blood glucose levels of $200 \mathrm{mg} / \mathrm{dL}$ or higher in rats have been accepted as diabetic [14]. Throughout the experiment, rat bloods were collected from daily tail veins. The blood glucose value was measured at $0 \mathrm{~h}$ (fasting blood glucose) and 1 and $2 \mathrm{~h}$ after treatment with plant extract.

\section{Evaluation of serum parameters}

Alanine aminotransferase, Aspartate aminotransferase, lactate dehydrogenase enzyme activity and creatinine, urea, blood glucose and lipid profile [(total cholesterol (TC), low-density lipoprotein cholesterol (LDL-C), triglyceride (TG) and high-density lipoprotein cholesterol (HDL-c)] levels were determined by photometry using ready kits via autoanalyser (Roche Hitachi Cobas integra 800). The levels of Glycolized $\mathrm{Hb}$ (HbA1c) in total blood were determined using the kit (DPC; Diagnostic Products Corporation, USA) via an autoanalyzer (Roche Hitachi integra 400-Plus). Alphaglucosidase enzyme activity in the intestine was analysed colorimetrically at $410 \mathrm{~nm}$ (hydrolyzing the substrate mixture to release $p$-nitrophenol). (BioVision kits, USA) [15].

\section{Statistical analysis}

Statistical analysis was carried out using Minitab (Minitab, State College, PA). Data are presented as mean \pm standard deviation (SD). One-way ANOVA was used to compare study groups. A significant difference at $p<0.05$ was applied for data comparison.

\section{RESULTS}

\section{Effect of Vicia ervilia seed extract on body weight and blood glucose levels}

Alterations in the first and end body weight of the control and empirical group are presented in Table 1. The difference between the initial and final body weights was found to be significant in the NC, DAC, and DMV400 groups ( $p \leq 0.05)$. Data on the blood glucose levels of the NC, DC, DAC, and V. ervilia extract (DMV100, DMV200, and DMV400) groups are also presented in Table 1. In the diabetic groups, blood glucose increased significantly compared with those in the NC group $(p \leq 0.05)$. Oral administration of $V$. ervilia extract and acarbose resulted in a significant reduction in blood glucose $(p \leq 0.05)$ in the DAC, DMV100 and DMV400 groups compared to those in the DC. HbA1c values increased significantly in DC and diabetic + extract groups compared to NC group $(p \leq 0.05)$. An increase in $\mathrm{HbA} 1 \mathrm{c}$ was observed in diabetic groups, however, a significant reduction in the DAC and DMV400 group was observed in comparison to the DC group ( $p \leq 0.05)$.

\section{Effect of $V$. ervilia extract on glycosylated $\mathrm{Hb}$ levels and $\alpha$-glucosidase activity}

As shown in Table 2, HbA1c showed a significant increase during the 25-day administration period in the diabetic groups. Compared to the levels in the diabetic control group (DC), the DMV200 and DMV400 groups showed a significant decrease in $\mathrm{HbA} 1 \mathrm{c}$ levels. In the DC group, a significant increase in $\alpha$ glucosidase activity was observed, as opposed to that in the NC group. However, no significant difference was found between the NC values of the activity of a-glucosidase enzyme compared to the NC group treated with $V$. ervillia extract ( $p$ $>0.05$ ). Alpha-glucosidase activity in diabetic rats treated with seed extract declined significantly compared to the DC group ( $p \leq 0.05)$.

\section{Effects of $V$. ervilia seed extract on lipid profile of diabetic rats}

In the control and experimental groups, rat lipid profiles are given in Table 3. There was a 
significant increase in total cholesterol, triglyceride, low-density lipoprotein cholesterol levels in streptozotocin-induced diabetic control rats compared to those in the normal control group, whereas there was a significant decrease in high-density lipoprotein cholesterol levels compared to those in the NC group $(p \leq 0.05)$. The decrease in trigliserid levels in the DVM400 group was not significant compared to the levels in the NC group $(p>0.05)$, whereas the decrease in total cholesterol levels was found to be significant $(p \leq 0.05)$. The rats to which the seed extracts were fed by gavage for 25 days (DAC, DMV100, and DMV200 groups) showed a significant increase in total cholesterol, trigliserid, and low-density lipoprotein cholesterol levels compared to the levels in the diabetic control group $(p \leq 0.05)$. However the DMV400 group exhibited a significant decrease in total cholesterol, trigliserid, and low-density lipoprotein cholesterol levels compared to those in the diabetic control group $(p \leq 0.05)$. The DAC group showed a significant increase in highdensity lipoprotein cholesterol levels compared to those of the DC group while the DMV100, DMV200, and DMV400 groups showed a significant decrease in high-density lipoprotein cholesterol levels $(p \leq 0.05)$.

Table 1: In streptozotocin-induced diabetic rats, the impact on body weight and blood glucose levels of $V$. ervilia seed extract and acarbose is 25 days

\begin{tabular}{lllllll} 
Parameter & NC & DC & DAC & DMV100 & DMV200 & DMV400 \\
\hline Initial body weight $(\boldsymbol{g})$ & $239.00 \pm 6.99$ & $284.83 \pm 6.08$ & $293.67 \pm 6.15$ & $264.83 \pm 2.32$ & $258.17 \pm 6.15$ & $235.33 \pm 5.16$ \\
After 25 days & $288.17 \pm 5.15$ & $265.33 \pm 2.42^{\mathrm{a}}$ & $313.50 \pm 6.83^{\mathrm{a}}$ & $267.00 \pm 4.73$ & $254.17 \pm 3.85$ & $252.33 \pm 4.68^{\mathrm{a}}$ \\
& & & & & & \\
Blood glucose $(\mathbf{m g} / \mathbf{d l})$ & & & & & \\
0 h (fasting blood glucose, $\mathrm{mg} / \mathrm{dl})$ & $112.50 \pm 8.80$ & $522.60 \pm 53.40$ & $507.26 \pm 23.82$ & $517.76 \pm 46.99$ & $558.88 \pm 23.73$ & $514.00 \pm 43.36$ \\
$1 \mathrm{~h}$ & $121.30 \pm 8.60$ & $511.60 \pm 53.90$ & $424.14 \pm 33.97^{\mathrm{D}}$ & $447.6 \pm 35.91^{\mathrm{D}}$ & $519.16 \pm 21.94^{\mathrm{D}}$ & $406.48 \pm 22.88^{\mathrm{D}}$ \\
$2 \mathrm{~h}$ & $117.80 \pm 7.40$ & $515.40 \pm 52.40$ & $429.34 \pm 34.86^{\mathrm{b}}$ & $443.86 \pm 34.96^{\mathrm{b}}$ & $473.68 \pm 45.56^{\mathrm{b}}$ & $395.82 \pm 27.98^{\mathrm{b}}$ \\
\hline
\end{tabular}

Data are shown as mean \pm SD $(\mathrm{n}=6)$. ${ }^{\mathrm{a}}$ Comparison of body weight final and initial $(p \leq 0.05) .{ }^{\mathrm{b}}$ Compared with 0 hours (before consumption) extract 1 and 2 hours (after consumption) $(p \leq 0.05)$. NC (normal control) DC (diabetic control), DAC (diabetes + acarbose $20 \mathrm{mg} / \mathrm{kg}$ group), DMV100 (diabetes + extract $100 \mathrm{mg} / \mathrm{kg}$ group), DMV200 (diabetes + extract 200 mg / kg group), DMV400 (diabetes + extract $400 \mathrm{mg} / \mathrm{kg}$ group)

Table 2: Effect of $V$. ervilia seed extract on glycosylated hemoglobin (HbA1c) levels and a-glucosidase activity

\begin{tabular}{|c|c|c|c|c|c|c|}
\hline \multirow[t]{2}{*}{ Parameter } & & \multicolumn{5}{|c|}{ Group } \\
\hline & $N C$ & $D C$ & $D A C$ & DMV100 & DMV200 & DMV400 \\
\hline $\begin{array}{l}\text { Glycosylated } \\
\mathrm{Hb}(\%)\end{array}$ & $3.56 \pm 0.14$ & $7.38 \pm 0.37^{\mathrm{a}}$ & $6.46 \pm 0.88^{a, b}$ & $7.67 \pm 0.79^{\mathrm{a}}$ & $7.42 \pm 0.20^{\mathrm{a}}$ & $6.80 \pm 0.50^{\mathrm{a}, \mathrm{b}}$ \\
\hline $\begin{array}{l}\alpha-G l u c o s i d a s e \\
\text { (U/mg protein) }\end{array}$ & $16.8 \pm 0.90$ & $22.1 \pm 0.40^{\mathrm{a}}$ & $15.6 \pm 0.8^{\mathrm{ab}}$ & $15.7 \pm 0.80^{b}$ & $18.6 \pm 0.30^{b}$ & $17.1 \pm 0.40^{b}$ \\
\hline \multicolumn{7}{|c|}{$\begin{array}{l}\text { Data are mean } \pm \text { SD }(\mathrm{n}=6) .{ }^{\mathrm{a}} \text { When DC, DAC, DMV100, DMV200 and DMV400 groups were compared with } \\
\text { NC group }(p \leq 0.05) ;{ }^{b} \text { When DAC, DMV100, DMV200 and DMV400 groups were compared with DC group ( } p \\
\leq 0.05 \text { ); NC (normal control) DC (diabetic control), DAC (diabetes + acarbose } 20 \mathrm{mg} / \mathrm{kg} \text { group), DMV100 } \\
\text { (diabetes + extract } 100 \mathrm{mg} / \mathrm{kg} \text { group), DMV200 (diabetes + extract } 200 \mathrm{mg} / \mathrm{kg} \text { group), DMV400 (diabetes } \\
+ \text { extract } 400 \mathrm{mg} / \mathrm{kg} \text { group) }\end{array}$} \\
\hline
\end{tabular}

Table 3: Effect of $V$. ervilia seed extract on lipid profile in rats

\begin{tabular}{|c|c|c|c|c|c|}
\hline \multirow[t]{2}{*}{ Parameter } & \multicolumn{5}{|c|}{ Group } \\
\hline & $N C$ & $D C$ & $D A C$ & DMV100 & DMV200 \\
\hline $\mathrm{TG}(\mathrm{mg} / \mathrm{dL})$ & $100.77 \pm 14.80$ & $142.03 \pm 11.32^{\mathrm{a}}$ & $165.50 \pm 32.02^{\mathrm{a}}$ & $128.60 \pm 10.85^{a}$ & $143.00 \pm 26.87^{\mathrm{a}}$ \\
\hline TC (mg/dL) & $53.50 \pm 2.88$ & $63.17 \pm 7.33^{\mathrm{a}}$ & $63 \pm 6.48^{\mathrm{a}}$ & $66.50 \pm 7.04^{\mathrm{a}}$ & $66.83 \pm 10.19^{a}$ \\
\hline $\begin{array}{l}\text { LDL-C } \\
(\mathrm{mg} / \mathrm{dL})\end{array}$ & $12.97 \pm 2.89$ & $22.12 \pm 2.98^{a}$ & $20.10 \pm 3.02^{a}$ & $22.62 \pm 3.97^{\mathrm{a}}$ & $22.12 \pm 4.48^{\mathrm{a}}$ \\
\hline $\begin{array}{l}\text { HDL-C } \\
(\mathrm{mg} / \mathrm{dL})\end{array}$ & $16.41 \pm 1.20$ & $11.79 \pm 2.65^{\mathrm{a}}$ & $27.80 \pm 0.94^{a . b}$ & $12.62 \pm 3.23^{\mathrm{a}}$ & $12.63 \pm 2.40^{a}$ \\
\hline \multicolumn{6}{|c|}{$\begin{array}{l}\text { The data are expressed as mean } \pm \text { SD }(n=6) .{ }^{a} \mathrm{DC}, \mathrm{DAC}, \mathrm{DMV} 100, \text { DMV200 and DMV400 groups were } \\
\text { compared with NC group ( } \mathrm{p} \leq 0.05) ;{ }^{\mathrm{b}} \mathrm{DAC} \text {, DMV100, DMV200 and DMV400 groups were compared with DC } \\
\text { group ( } \mathrm{p} \leq 0.05) ; \mathrm{NC} \text { (normal control) DC (diabetic control), DAC (diabetes + acarbose } 20 \mathrm{mg} / \mathrm{kg} \text { group), } \\
\text { DMV100 (diabetes + extract } 100 \mathrm{mg} / \mathrm{kg} \text { group), DMV200 (diabetes + extract } 200 \mathrm{mg} / \mathrm{kg} \text { group), DMV400 } \\
\text { (diabetes + extract } 400 \mathrm{mg} / \mathrm{kg} \text { group) }\end{array}$} \\
\hline
\end{tabular}




\section{Effect of $V$. ervilia on liver and renal serum biomarkers}

Table 4 summarizes control and test group serum liver enzyme biomarkers. The alanine aminotransferase and aspartate aminotransferase enzyme levels increased significantly in all diabetic groups compared to NC group ( $p \leq 0.05$ ). However, there was a significant decrease in serum alanine aminotransferase and aspartate aminotransferase levels in the groups in which the extract was administered compared to the DC group. In the extract groups, the levels of serum lactate dehydrogenase were significantly reduced compared to NC and DC groups ( $p \leq 0.05$ ). Serum urea levels increased in all $V$. ervilia seed extract groups compared to NC group ( $p \leq 0.05$ ), whereas serum urea levels in DMV100 and DMV200 groups decreased compared to DC groups ( $p \leq 0.05)$. Serum creatinine levels of all the extract treated and DAC groups were significantly increased compared to the DC group ( $p \leq 0.05)$.

\section{DISCUSSION}

In rats with diabetes induced by STZ is a suitable model used to investigate antidiabetic agents [16]. The purpose of this study was to investigate the effect of $V$. ervilia seed extract (DMV100, DMV200, DMV400) on serum glycemic, serum lipid profile, kidney and liver biomarkers in STZ-induced diabetic rats. Diabetes caused by STZ is defined by serious body weight loss. Control of weight loss during the treatment of diabetes is an important issue in terms of determining the course of treatment. The restorative effect of plant extracts and antidiabetic agents has been reported to be due to the reversal of gluconeogenesis and glycogenolysis [17]. A significant increase in body weight in DAC and DMV400 groups showed that $V$. ervilia seed extract decreased hyperglycemia. Plants with antidiabetic activity employ various mechanisms in living organisms (increasing insulin sensitivity and secretion, stimulating regeneration in Langerhans islets and preventing free radicals) [18]. In this study, $V$. ervilia seed extract shows that it has a lowering effect on blood glucose levels in diabetic rats. The antihyperglycemic effect of Vicia ervilia may be caused by stimulating the secretion of insulin from $\beta$-cells in the islets of Langerhans via prevention of the formation of free radicals caused by STZ. The effect of $V$. ervilia seed extract on glycosylated hemoglobin levels $(\mathrm{HbA} 1 \mathrm{c})$ and $\alpha$-glucosidase activity is presented in Table 2. The majority of metabolic disorders has been reported to increase $\mathrm{HbA1c}$ and TBARS levels in diabetic animals and to decrease serum insulin and C-peptide levels. $\mathrm{HbA1c}$ is used to monitor glycemic control in diabetic patients and is considered to be an important biomarker for the development and improvement of chronic diabetic complications [19]. In this study, the HbA1c levels increased significantly in all the diabetic groups compared to those in the NC group, whereas the DAC and DMV400 groups showed a significant decrease compared to those in the DC group. This may be due to the positive effect of the seed extract on glucose metabolism, resulting in improved glycemic control.

The enzyme a-glucosidase performs specific metabolic functions in the digestion of carbohydrates. If this enzyme is inhibited, the digestion of complex sugars may be delayed and an excessive increase in postprandial blood glucose is observed [20]. According to NC, the increase in a-glucosidase activity in DC was higher in this study.

Table 4: Effect of $V$. ervilia seed extract on liver, serum and kidney biomarkers

\begin{tabular}{lcccccc}
\hline & \multicolumn{5}{c}{ Group } \\
\cline { 2 - 6 } Parameter & NC & DC & DAC & DMV100 & DMV200 & DMV400 \\
\hline AST (U/L) & $3.56 \pm 0.14$ & $7.38 \pm 0.37^{\mathrm{a}}$ & $6.46 \pm 0.88^{\mathrm{a}, \mathrm{b}}$ & $7.67 \pm 0.79^{\mathrm{a}}$ & $7.42 \pm 0.20^{\mathrm{a}}$ & $6.80 \pm 0.50^{\mathrm{a}, \mathrm{b}}$ \\
ALT (U/L) & $1.68 \pm 0.09$ & $2.21 \pm 0,04^{\mathrm{a}}$ & $1,56 \pm 0,08^{\mathrm{ab}}$ & $1.57 \pm 0,08^{\mathrm{b}}$ & $1.86 \pm 0.03^{\mathrm{b}}$ & $1.71 \pm 0.04^{\mathrm{b}}$ \\
LDH (U/L) & $1115.1 \pm 164.20$ & $1168 \pm 287.10$ & $1222.5 \pm 146.20$ & $735.4 \pm 172.20^{\mathrm{a}, \mathrm{b}}$ & $528.1 \pm 57.70^{\mathrm{a}, \mathrm{b}}$ & $568.4 \pm 157.50^{\mathrm{a}, \mathrm{b}}$ \\
Creatinine & $0.29 \pm 0.04$ & $0.37 \pm 0.02^{\mathrm{a}}$ & $0.32 \pm 0.03^{\mathrm{b}}$ & $0.32 \pm 0.04^{\mathrm{b}}$ & $0.32 \pm 0.03^{\mathrm{b}}$ & $0.33 \pm 0.04^{\mathrm{b}}$ \\
(mg/dL) & & & & & \\
Urea & $46.17 \pm 5.40$ & $69.00 \pm 19.28^{\mathrm{a}}$ & $51.00 \pm 25.20^{\mathrm{b}}$ & $53.17 \pm 29.20^{\mathrm{a} . \mathrm{b}}$ & $59.00 \pm 23.33^{\mathrm{a}, \mathrm{b}}$ & $62.33 \pm 14.60^{\mathrm{a}}$ \\
(mg/dL) & & & & & \\
\hline
\end{tabular}

Data are expressed as mean \pm SD $(n=6) .{ }^{a}$ DC, DAC, DMV100, DMV200 and DMV400 groups were compared with NC group ( $\mathrm{p} \leq 0.05) ;{ }^{b} \mathrm{DAC}$, DMV100, DMV200 and DMV400 groups were compared with DC group ( $p \leq 0.05$ ); $\mathrm{NC}$ (normal control) DC (diabetic control), DAC (diabetes + acarbose $20 \mathrm{mg} / \mathrm{kg}$ group), DMV100 (diabetes + extract $100 \mathrm{mg} / \mathrm{kg}$ group), DMV200 (diabetes + extract $200 \mathrm{mg} / \mathrm{kg}$ group), DMV400 (diabetes + extract $400 \mathrm{mg} / \mathrm{kg}$ group) 
However, the activity of this enzyme in the diabetic groups treated with the seed extract demonstrated an important decline compared to that at the DC group. This may be due to the seed extract's inhibitory influence on the $\alpha$ glucosidase enzyme.

The impact of $V$. ervilia seed extract on lipid profile is represented in Table 3. High levels of $\mathrm{TC}, \mathrm{TG}$, and LDL-C in diabetes are associated with lipid metabolism dysfunctions. Normally, the lipoprotein lipase enzyme is activated by insulin and it hydrolyzes TGs in lipoproteins. Insulin deficiency in the diabetic state inactivates the lipoprotein lipase enzyme. The result is defined as hypertriglyceridemia. Insulin deficiency is also associated with hypercholesterolemia. Secretion of lipoprotein cholesterol very low density is stimulated by triglycerides. The rise in these molecules reduces the level of HDL-c and increases the level of LDL-c. Furthermore, high serum TG levels, low serum HDL-C, and superiority of LDL-C particles are considered strong risk factors in DM for cardiovascular diseases [21]. In this study, total cholesterol, total glyceride, and low-density lipoprotein values were notably rising in diabetic rats compared to those of controls. It was observed that total cholesterol, total glyceride, and low-density lipoprotein values decreased when compared with the DC group of seed extract groups. Based on these results, it can be concluded that the seed extract used prevents the progression of diabetes-related complications associated with lipid metabolism. Diabetic nephropathy is one of the major complications in these patients. It is the most important reason, of renal insufficiency and it is seen in nearly half of the patients. Renal hypertrophy develops in diabetic nephropathy. In addition, significant changes in morphology and function have been reported [22]. The main factors that play a role in the pathogenesis of diabetic nephropathy are oxidative stress and chronic kidney inflammation. Hyperglycemiarelated reactive oxygen species (ROS) formation is closely related to diabetic nephropathy initiation and progression. Studies have reported a reduction in antioxidant defense function and a rise in oxidative stress in patients with streptozotocin-induced diabetic nephropathy [23]. The results of the present study show that urea (DMV100 and DMV200 groups) and creatinine levels decreased in all diabetic extract groups compared to those of the DC group, indicating that $V$. ervilia may have a healing effect on increased oxidative stress in diabetes. High ROS production in diabetes leads to oxidative stress. This leads to the dysfunction of structural biomolecules in cells and thus in organs [24]. Increase in serum ALT, AST and LDH levels is a consequence of cellular leakage due to disruption of the hepatic membrane [25]. In this study, the increase in ALT and AST levels in the diabetic groups compared to those in the normal control group showed diabetes-induced liver damage $(p \leq 0.05)$. In all diabetic groups treated with $V$. ervilia seed extract, ALT, AST and LDH values increased significantly compared to NC group. In the groups treated with seed extract, these enzyme levels decreased significantly compared to the DC group. According to these data, it can be concluded that $V$. ervilia seed extract is effective in preventing liver damage caused by diabetes.

\section{CONCLUSION}

The findings of this study show that lyophilized $V$. ervilia seed extract reduces the blood glucose of diabetic rats. In addition, the exerts a positive effect on lipid profile as well as liver and kidney biomarkers of rats when compared to DC. However, there is a need to investigate the chemical composition of this plant seed in view if its use in the treatment of diabetes in folk medicine.

\section{DECLARATIONS}

\section{Acknowledgement}

It was supported by the project code of VYYU2014-FBE-YL098 coordinating the Scientific Research Projects of Van Yuzuncu Yil University. The authors are grateful for the support provided.

\section{Conflict of interest}

No conflict of interest is associated with this work. This study constitutes the main part of the Master's degree thesis of Derya Kartal. None of the authors has any commercial or financial interest, and/or any other relationship with the commercial suppliers of medicines, laboratory equipment and/or medical device manufacturers or commercially available services.

\section{Contribution of authors}

We declare that this work was done by the authors named in this article and all liabilities pertaining to claims relating to the content of this article will be borne by the authors.

\section{Open Access}

This is an Open Access article that uses a funding model which does not charge readers or their institutions for access and distributed under the 
terms of the Creative Commons Attribution License (http://creativecommons.org/licenses/by/ 4.0) and the Budapest Open Access Initiative (http://www.budapestopenaccessinitiative.org/rea d), which permit unrestricted use, distribution, and reproduction in any medium, provided the original work is properly credited.

\section{REFERENCES}

1. American Diabetes Association (ADA), Classification and diagnosis of diabetes. Diabetes Care 2016; 38 (2): 8-16.

2. Al-Faris NA, Al-sawadi AD, Alokai MS. Effect of samh seeds supplementation (Mesembryanthemum forsskalei Hochst) on liver enzymes and lipid profiles of streptozotocin (STZ)-induced diabetic Wistar rats. Saudi J Biol Sci 2010; 17(1):23-28.

3. Negre-Salvayr A, Coatrieux $C$, Ingueneau $C$, Salvayre $R$. Advanced lipid peroxidation end products in oxidative damage to proteins. Potential role in diseases and therapeutic prospects for the inhibitors. Br J Pharmacol 2008;153(1): 6-20.

4. Zimmet $P$, Alberti KG, Magliano DJ, Bennett $P H$. Diabetes mellitus statistics on prevalence and mortality: facts and fallacies. Nat Rev Endocrinol 2016; 12(10): 616.

5. Kumar $R$, Arora $V$, Ram $V$, Bhandari $A$, Vyas $P$. Hypoglycemic and hypolipidemic effect of Allopolyherbal formulations in streptozotocin induced diabetes mellitus in rats. Int J Diabetes Mellit 2015; 3(1): 45-50.

6. Ota A, Ulri, NP. An overview of herbal products and secondary metabolites used for management of type two diabetes. Frontiers in pharmacology 2017; 8: 436.

7. Mishra A, Jailty AK, Srivastava AK. Antihyperglycemic activity of six edible plants in validated animal models of diabetes mellitus. Indian J Sci Technol 2009; 2(4):80-6.

8. Baytop T. Türkiyede bitkiler ile tedavi (geçmişte ve bugün) (Vol. 40). İstanbul Üniversitesi, 1984.

9. Kaisoon O, Konczak I, Siriamornpun, SPotential health enhancing properties of edible flowers from Thailand. Food Res Int 2012; 46(2): 563-571.

10. Kregel KC, Allen DL, Booth FW, Fleshner MR, Henrikson EJ, Musch TI, Sheriff DD. Exercise Protocols Using Rats and Mice In: Resource book for the design of animal exercise protocols. 2006:23-57.

11. GUIDELINE, OECD OECD. 425: acute oral toxicity-upand-down procedure. OECD Guidelines for the Testing of Chemicals 2001; (2): 12-16.

12. Dalar A, Dogan A, Bengu AS, Mukemre M, Celik I. Screening in vivo antioxidant and haematological properties of sumac and acorn bioactive rich extracts. Ind Crops Prod 2018; 124: 20-27.)

13. Ozok N, Celik I. Effects of subacute and subchronic treatment of synthetic plant growth regulators on liver damage serum biomarkers tissue antioxidant defense systems and lipid peroxidation in rats. J Drug Metab Toxicol 2012; 3(124): 2.

14. Kanitkar M, Bhonde R. Existence of islet regenerating factors within the pancreas. Rev Diabet Stud 2004; 1(4), 185.

15. Kale OE, Akinpelu OB, Bakare AA, Yusuf FO, Gomba R, Araka $D C$, Odutola $O$. Five traditional Nigerian Polyherbal remedies protect against high fructose fed, Streptozotocin-induced type 2 diabetes in male Wistar rats. BMC Complement Altern Med 2018. 18(1): 160.

16. Eddouks M, Chattopadhyay D, Zeggwagh NA. Animal models as tools to investigate antidiabetic and antiinflammatory plants. Evid Based Complement Alternat Med 2012.

17. Kandhare A, Phadke U, Mane A, Thakurdesai $P$, Bhaskaran S. Add-on therapy of herbal formulation rich in standardized fenugreek seed extract in type 2 diabetes mellitus patients with insulin therapy: An efficacy and safety study. Asian Pac J Trop Biomed 2018; 8(9): 446.

18. Sezik E, Aslan M, Yesilada E, Ito S. Hypoglycemic activity of Gentiana olivieri and isolation of the active constituent through bioassay-directed fractionation techni- ques. Life Sci 2005; 76: 1223-1238

19. Katare DP. Effect of ethanolic extract of Euphorbia hirta on chronic diabetes mellitus and associated cardiorenal damage in rats. International Journal of Green Pharmacy (IJGP) 2018; 12(03).

20. Molehin OR, Oloyede OI, Adefegha SA. Streptozotocininduced diabetes in rats: effects of white butterfly (Clerodendrum volubile) leaves on blood glucose levels, lipid profile and antioxidant status. Toxicol Mech Methods 2018; 28(8): 573-586.

21. Ikewuchi CC. Alteration of plasma lipid profiles and atherogenic indices by Stachytarpheta jamaicensis L.(Vahl). Biokemistri 2009; 21(2).

22. Zhang C, Li Q, Lai S, Yang L, Shi G, Wang Q, Yu Y. Attenuation of diabetic nephropathy by Sanziguben Granule inhibiting EMT through Nrf2-mediated antioxidative effects in streptozotocin (STZ)-induced diabetic rats. J Ethnopharmacol 2017; 205: 207-216.

23. Olatunji OJ, Chen H, Zhou Y. Lycium chinense leaves extract ameliorates diabetic nephropathy by suppressing hyperglycemia mediated renal oxidative stress and inflammation. Biomed Pharmacother 2018; 102: 11451151.

24. Bamagous GA, Al Ghamdi SS, Ibrahim IAA, Mahfoz AM, Afify MA, Alsugoor MH, Rengarajan T. Antidiabetic and antioxidant activity of ethyl acetate extract fraction of Moringa oleifera leaves in streptozotocin-induced diabetes rats via inhibition of inflammatory mediators. Asian Pac J Trop Biomed 2018; 8(6): 320.

25. Annadurai T, Muralidharan AR, Joseph T, Hsu MJ, Thomas PA, Geraldine P. Antihyperglycemic and antioxidant effects of a flavanone, naringenin, in streptozotocin-nicotinamide-induced experimental diabetic rats. J Biochem Physiol 2012; 68(3): 307-318. 